\title{
Radioimmunoassay of Human Fibrinopeptide B and Kinetics of Fibrinopeptide Cleavage by Different Enzymes
}

\author{
Sophie B. Bilezikian, Hymie L. Nossel, Vincent P. Butler, Jr., and \\ ROBERT E. CANFIELD \\ From the Department of Medicine, Columbia University College of Physicians \\ and Surgeons, New York 10032
}

\begin{abstract}
A B S T RACT Thrombin converts fibrinogen to fibrin monomer by cleaving fibrinopeptides $\mathrm{A}$ and $\mathrm{B}$ (FPA and FPB) from the amino terminal ends of the $\mathrm{A}(\alpha)$ and $B(\beta)$ chains. $A$ radioimmunoassay capable of measuring the A peptide in human blood as an index of thrombin action in vivo has been described previously. This paper describes the development of a radioimmunoassay for FPB and the use of both assays in the demonstration of distinctive patterns of cleavage of the amino terminal ends of the $\mathrm{A}(\alpha)$ and $\mathrm{B}(\boldsymbol{\beta})$ chains of fibrinogen by various enzymes.
\end{abstract}

Antisera were raised in rabbits to a synthetic analogue of FPB coupled to bovine serum albumin. FPB analogue was coupled to desaminotyrosine and radiolabeled with ${ }^{205} \mathrm{I}$ by the chloramine- $\mathrm{T}$ technique. The radiolabeled peptide was bound by the antiserum, and binding was inhibited by synthetic or native FPB. Unbound tracer was separated from bound tracer by charcoal adsorption. The sensitivity of the assay was such that $50 \%$ inhibition of binding of the tracer was caused by $1.25 \mathrm{ng}$ of the native FPB.

Fibrinogen was treated with thrombin, plasmin, trypsin, Reptilase, and an extract of the venom from Ancistrodon contortrix contortrix (ACC). After ethanol precipitation and centrifugation, dialysates of enzymatically altered fibrinogen were assayed for FPA and FPB. The action of thrombin on fibrinogen resulted in a rapid release of FPA and a slower release of $\mathrm{FPB}$.

Dr. Nossel is the recipient of Career Development Award HL-46355; Dr. Bilezikian is a New York Heart Association Research Fellow; and Dr. Butler is the recipient of a Career Scientist Award from the Irma T. Hirschl Foundation.

Received for publication 10 January 1975 and in revised form 27 March 1975.
Plasmin cleaved a segment $(s)$ of the $B(\beta)$ chain which included FPB but cleaved no detectable FPA-containing material for the first $2 \mathrm{~h}$ of incubation. In the case of plasmin-treated fibrinogen, the dialysates had been further treated with thrombin before being assayed for FPA and FPB. Trypsin rapidly cleaved both peptides, the $B$ before the $A$. Reptilase cleaved only FPA in $24 \mathrm{~h}$. ACC cleaved FPB at a rapid rate, with a slower cleavage of FPA. The distinctive cleavage patterns produced by the serine proteases may be useful in interpreting the levels of FPA and FPB measured in human blood and in studying the generation of FPA and FPB in clinical blood samples.

\section{INTRODUCTION}

Coagulation of fibrinogen follows its enzymatic conversion by thrombin to fibrin monomer in a limited proteolytic reaction in which fibrinopeptides $\mathrm{A}$ and $\mathrm{B}$ $(\text { FPA and FPB })^{1}$ are removed $(1,2)$. Thrombin action is thought to participate in physiological hemostasis and in pathological circumstances such as thrombosis and disseminated intravascular coagulation. The measurement of thrombin action in vivo would provide information about the pathophysiology, diagnosis, and treatment of disorders associated with intravascular coagulation. A radioimmunoassay for FPA has been developed (3) and used to measure the peptide in human plasma as an index of thrombin action in vivo (4). However, enzymes other than thrombin may also

\footnotetext{
${ }^{1}$ Abbreviations used in this paper: FPA, FPB, fibrinopeptides A and B; ACC, Ancistrodon contortrix contortrix. $N$-desaminotyrosyl FPB is used for ( $p$-hydroxyphenyl)propionyl, FPB analogue.
} 
cleave FPA or fragments containing it from fibrinogen. To permit a more specific interpretation of clinical data, a radioimmunoassay for $\mathrm{FPB}$ was developed and the kinetics of cleavage of both peptides from fibrinogen were studied to determine whether distinctive cleavage patterns for different enzymes could be obtained. This paper describes the radioimmunoassay for FPB and its use, along with the previously reported assay for FPA, in the study of the kinetics of cleavage of the amino terminal ends of the $\mathrm{A}(\alpha)$ and $\mathrm{B}(\boldsymbol{\beta})$ chains of fibrinogen by thrombin, plasmin, trypsin, and the snake venoms from Bothrops atrox (Reptilase) and Ancistrodon contortrix contortrix.

\section{METHODS}

Synthetic FPA and FPB and synthetic FPB analogue were obtained from Schwarz/Mann Div., Becton, Dickinson \& Co., Orangeburg, N. Y. The FPB analogue differed from the native peptide in having amino terminal glutamic acid in place of pyroglutamic acid. The amino acid compositions of the FPB preparations are given in Table $I$. The amino acid analyses were made with a Beckman automatic amino acid analyzer model 121 (Beckman Instruments, Inc., Fullerton, Calif.). Native FPB and human fibrinogen were the gift of Dr. Birger Blombäck of the Coagulation Department, Karolinska Institute, Stockholm, Sweden. Human plasmin (sp act $10 \mathrm{CTA} \mathrm{U} / \mathrm{mg})^{2}$ prepared by Dr. Per Wallén was given to us by Dr. Blombäck. Human thrombin (sp act 2,500 NIH U/mg) was isolated by Dr. Kent Miller (6) and given to us by Dr. D. Aronson of the Bureau of Biologics, Bethesda, Md. Trypsin (TRL 3 3DC, $202 \mathrm{U} / \mathrm{mg}$ ) was obtained from Worthington Biochemical Corp., Freehold, N. J. Purified Reptilase was the gift of Dr. Kurt Stocker, Pentapharm, Zurich, Switzerland. An extract of the procoagulant fraction of the venom of the Southern Copperhead, Ancistrodon contortrix contortrix (ACC) was the gift of Dr. John Finlayson, Bureau of Biologics, Bethesda, Md. Ovalbumin was obtained from Schwarz/Mann. Charcoal (Norit A) was obtained from the Amend Drug and Chemical Co., Irvington, N. J. Norit PQF from Eastman Organic Chemicals Div., Eastman Kodak Co., Rochester, N. Y., was equally satisfactory. Cohn fractions of human plasma, lysozyme, bovine and human serum albumin, and insulin were obtained from Nutritional Biochemicals Corp., Cleveland, Ohio. Bradykinin was obtained from Schwarz/Mann.

Preparation of immunogens. Synthetic FPB analogue was coupled to bovine serum albumin as follows. At room temperature, $2 \mathrm{ml} 0.021 \mathrm{M}$ glutaraldehyde in $0.1 \mathrm{M}$ sodium phosphate buffer ( $\mathrm{pH} 7.0$ ) was added dropwise with constant stirring to a mixture of $8 \mathrm{mg} \mathrm{FPB}$ analogue and $40 \mathrm{mg}$ bovine serum albumin in $4 \mathrm{ml} 0.1 \mathrm{M}$ sodium phosphate buffer ( $\mathrm{pH} 7.0$ ). After $2 \mathrm{~h}$ of stirring, the reaction mixture was dialyzed for $24 \mathrm{~h}$ against several changes of $0.15 \mathrm{M}$ sodium barbital-buffered saline $(\mathrm{pH} 7.4)$ and then lyophilized. The final yield was $96 \mathrm{mg}$ of material of which approximately $50 \%$ was buffer salts and sodium chloride.

Antisera. $8 \mathrm{mg}$ of the lyophilized material containing approximately $4 \mathrm{mg}$ of the bovine serum albumin-FPB conjugate was dissolved in $2 \mathrm{ml} 0.15 \mathrm{M} \mathrm{NaCl}$ and thoroughly mixed in a syringe with $2 \mathrm{ml}$ of complete Freund's adjuvant until it had thickened. After preimmunization sera

\footnotetext{
'CTA, Committee on Thrombolytic Agents.
}

TABLE I

Amino Acid Composition of Native FPB and FPB Analogue

\begin{tabular}{llcc}
\hline & $\begin{array}{c}\text { Theoretic native } \\
\text { FPB (reference 5) }\end{array}$ & $\begin{array}{c}\text { Native } \\
\text { FPB }\end{array}$ & $\begin{array}{c}\text { Synthetic } \\
\text { FPB } \\
\text { analogue }\end{array}$ \\
\hline Aspartic acid & 1 (2 Asparagine) & 2.89 & 3.31 \\
Serine & 1 & 0.96 & 1.07 \\
Glutamic acid & 2 (1 Pyroglutamic) & 2.99 & 3.11 \\
Glycine & 2 & 2.04 & 2.0 \\
Alanine & 1 & 1.03 & 1.0 \\
Valine & 1 & 1.03 & 1.05 \\
Phenylalanine & 2 & 2.04 & 1.94 \\
Arginine & 1 & 1.02 & 1.00 \\
\hline
\end{tabular}

had been obtained, white New Zealand rabbits were injected with the mixture according to the following schedule: $0.1 \mathrm{ml}$ in each front toe pad and $0.2 \mathrm{ml}$ in each rear toe pad at 1-wk intervals for a total of $3 \mathrm{wk}$; then $0.5 \mathrm{ml}$ intramuscularly in the haunches every 2 wk. Rabbit RB29 was immunized by a different technique. $4.8 \mathrm{mg}$ of lyophilized antigen was mixed with $2 \mathrm{ml}$ of sodium barbitalbuffered saline ( $\mathrm{pH} 7.4$ ) and $2 \mathrm{ml}$ of complete Freund's adjuvant. $1.5 \mathrm{ml}$ of this mixture was injected intradermally on the back in 50 sites. In addition, the rabbit received 0.3 $\mathrm{ml}$ in the abdominal wall and $0.2 \mathrm{ml}$ in each rear toe pad; $0.5 \mathrm{ml}$ was injected in the haunches every 2 wk thereafter.

Sera from all the rabbits showed a significant capacity to bind radiolabeled FPB analogue after 3 mo of immunization. Control sera were obtained from rabbits immunized in a similar manner with bovine serum albumin and human serum albumin, respectively.

Radiolabeled FPB analogue. Desaminotyrosine was coupled to the synthetic analogue of FPB by the method of Goodfriend and Ball (7). $4 \mathrm{mg}$ synthetic peptide mixed with $25 \mathrm{mg}$ of 3-( $p$-hydroxyphenyl) propionic acid- $p$-nitrophenyl ester (Cyclo Chemical Corp. Div., Travenol Laboratories, Inc., Los Angeles, Calif.) was added to 2.5 $\mathrm{ml}$ dimethylformamide (Mallinckrodt Chemical Works, St. Louis, Mo.). After stirring the mixture constantly for $18 \mathrm{~h}$ at $37^{\circ} \mathrm{C}, 2 \mathrm{ml}$ distilled water and $0.2 \mathrm{ml} 10 \%$ acetic acid were added. Initially a yellow precipitate formed which soon turned white. The mixture was then extracted with $15 \mathrm{ml}$ of a $1: 1$ ( $\mathrm{vol} / \mathrm{vol}$ ) chloroformethyl ether solution. After centrifugation at $500 \mathrm{~g}$ for 5 min at room temperature three phases separated; a lower phase of chloroform-ethyl ether, a dense white emulsion at the interphase, and at the top, a clear water phase. The water phase was re-extracted with $15 \mathrm{ml}$ chloroform-ethyl ether and lyophilized. The lyophilized sample was dissolved in $1 \mathrm{ml}$ of $0.1 \mathrm{M} \mathrm{NH} \mathrm{HCO}_{3}$, applied to a $20 \times 1.2-\mathrm{cm}$ column of Biogel P-2 (Calbiochem, San Diego, Calif.) suspended in $0.1 \mathrm{M} \mathrm{NH} 4 \mathrm{HCO}_{3}$, and eluted with the same buffer. The contents of the 11th $\mathrm{ml}$ of eluate showed a peak of ninhydrin reactivity after alkaline hydrolysis as well as maximal absorbance at $280 \mathrm{~nm}$. The peptide content of the fraction was estimated from the ninhydrin reactivity, and the tyrosine content was estimated by comparing the absorbance at $280 \mathrm{~nm}$ of the fraction with that of standard solutions of tyrosine and desaminotyrosine. From these data. it was estimated that the coupling of desaminotyrosine to the synthetic FPB analogue was approximately $1: 1$ on a molar basis.

The desaminotyrosine coupled peptide was radiolabeled by the method of Hunter and Greenwood (8). $30 \mu 10.5 \mathrm{M}$ sodium phosphate buffer $(\mathrm{pH} \quad 7.5)$ and $5 \mu \mathrm{l}$ carrier-free 
TABLE II

Binding of Radiolabeled Tyrosinated FBP Analogue

\begin{tabular}{|c|c|c|c|}
\hline Rabbit & Nature of serum & Dilution & $\begin{array}{l}\text { Radio- } \\
\text { activity } \\
\text { bound } \\
(\%)\end{array}$ \\
\hline RB22 & Preimmunization & $\begin{array}{l}1 / 20 \\
1 / 80\end{array}$ & $\begin{array}{l}0.8 \\
0.2\end{array}$ \\
\hline RB23 & Preimmunization & $\begin{array}{l}1 / 20 \\
1 / 80\end{array}$ & $\begin{array}{l}0.3 \\
0.2\end{array}$ \\
\hline RB24 & Preimmunization & $\begin{array}{l}1 / 20 \\
1 / 80\end{array}$ & $\begin{array}{l}1.1 \\
0.5\end{array}$ \\
\hline RB29 & Preimmunization & $1 / 10$ & 3.6 \\
\hline RB22 & $\begin{array}{l}\text { Immunized with FPB- } \\
\text { bovine albumin }\end{array}$ & $\begin{array}{l}1 / 20 \\
1 / 100 \\
1 / 500 \\
1 / 800 \\
1 / 1000\end{array}$ & $\begin{array}{l}72 \\
43 \\
29 \\
22 \\
20\end{array}$ \\
\hline RB23 & $\begin{array}{l}\text { Immunized with FPB- } \\
\text { bovine albumin }\end{array}$ & $\begin{array}{l}1 / 20 \\
1 / 100 \\
1 / 200 \\
1 / 500 \\
1 / 800 \\
1 / 1000\end{array}$ & $\begin{array}{l}65 \\
38 \\
30 \\
18 \\
15 \\
11\end{array}$ \\
\hline RB24 & $\begin{array}{l}\text { Immunized with FPB- } \\
\text { bovine albumin }\end{array}$ & $\begin{array}{l}1 / 20 \\
1 / 80\end{array}$ & $\begin{array}{l}52 \\
37\end{array}$ \\
\hline RB29 & $\begin{array}{l}\text { Immunized with FPB- } \\
\text { bovine albumin }\end{array}$ & $\begin{array}{l}1 / 200 \\
1 / 400 \\
1 / 800\end{array}$ & $\begin{array}{l}51 \\
45 \\
34\end{array}$ \\
\hline 55 & Antifibrinogen (from C. Merskey) & $\begin{array}{l}1 / 10 \\
1 / 50\end{array}$ & $\begin{array}{l}1.1 \\
0.3\end{array}$ \\
\hline & $\begin{array}{l}\text { Antifibrinogen (Hyland Div., } \\
\text { Travenol Laboratories, Inc., } \\
\text { Costa Mesa, Calif. } \\
\text { 8108H003B 1) }\end{array}$ & $\begin{array}{l}1 / 10 \\
1 / 50\end{array}$ & $\begin{array}{l}2.6 \\
0.3\end{array}$ \\
\hline & Antibovine serum albumin & $\begin{array}{l}1 / 10 \\
1 / 20\end{array}$ & $\begin{array}{l}2.3 \\
2.1\end{array}$ \\
\hline & Antihuman serum albumin & $\begin{array}{l}1 / 10 \\
1 / 20\end{array}$ & $\begin{array}{l}5.0 \\
3.1\end{array}$ \\
\hline
\end{tabular}

$0.1 \mathrm{ml}$ antiserum at the indicated concentration was incubated for $24 \mathrm{~h}$ at $4^{\circ} \mathrm{C}$ with ${ }^{126} \mathrm{I}$-labeled tyrosinated $\mathrm{B}$ peptide analogue in a final volume of $0.5 \mathrm{ml}$. Bound tracer was separated from free tracer with the charcoal adsorption technique.

${ }^{125} \mathrm{I}(1 \mathrm{mCi})$, (Union Carbide Corp., New York), in 0.05 $\mathrm{M} \mathrm{NaOH}$ were mixed in a $0.3-\mathrm{ml}$ microflex $\mathrm{V}$ tube (Kontes Glass Co., Vineland, N. J.), and $30 \mu 1$ desaminotyrosinated peptide $(11 \mu \mathrm{g})$ in $0.1 \mathrm{M} \mathrm{NH}_{4} \mathrm{HCO}_{3}$ was added. $15 \mu 1$ chloramine- $\mathrm{T}(25 \mu \mathrm{g})$ and, after $30 \mathrm{~s}, 20 \mu \mathrm{l}$ of sodium metabisulfite $(48 \mu \mathrm{g})$ were added. The chloramine-T and sodium metabisulfite were dissolved in $0.5 \mathrm{M}$ sodium phosphate buffer ( $\mathrm{pH} 7.5)$. After a further $30 \mathrm{~s}, 20 \mu \mathrm{l}$ rabbit serum albumin and $200 \mu 10.5 \mathrm{M}$ sodium phosphate buffer ( $\mathrm{pH} 7.5$ ) were added. The mixture was passed over a $1.2 \times 10-\mathrm{cm}$ Sephadex G-10 column equilibrated with $0.1 \mathrm{M} \mathrm{NaCl}$ buffered with $0.05 \mathrm{M}$ Tris- $\mathrm{HCl}$ at $\mathrm{pH}$ 7.5. 0.5$\mathrm{ml}$ fractions were collected and radioactivity was counted. The early peak of radioactivity (usually the ninth fraction) containing the radiolabeled antigen was diluted for use in the assay to provide approximately $10,000 \mathrm{cpm}$ per $50 \mu 1$.

Radioimmunoassay. The preparations of antisera, immunogens, and radiolabeled tracer for the FPA assay have been previously described $(3,4)$. Radioimmunoassays for both FPA and FPB were performed in the same way. The technique differed slightly from that previously described. Test samples, antiserum, and tracer were all diluted in 0.1 $\mathrm{M} \mathrm{NaCl}$ buffered with $0.05 \mathrm{M}$ Tris- $\mathrm{HCl}$ at $\mathrm{pH} 8.6$ and containing $0.1 \%$ ovalbumin. To $250 \mu \mathrm{l}$ of buffer was added $100 \mu \mathrm{l}$ of test sample, followed by $50 \mu \mathrm{l}$ of tracer. $100 \mu 1$ of antiserum diluted to give between 40 and $50 \%$ binding of the tracer was then added. Inhibition of binding of the radiolabeled tracer was tested each day with known amounts of standard solutions of synthetic FPA or native FPB. The tubes were incubated for $90 \mathrm{~min}$ at $4^{\circ} \mathrm{C}$. Unbound tracer was adsorbed by the addition of $0.5 \mathrm{ml}$ of a charcoal mixture followed by centrifugation at $1,700 \mathrm{~g}$ for $10 \mathrm{~min}$. The charcoal was a $2.5 \%$ suspension in $0.1 \mathrm{M} \mathrm{NaCl}$ buffered with $0.05 \mathrm{M}$ Tris- $\mathrm{HCl}$ at $\mathrm{pH} 8.6$ containing $0.4 \%$ ovalbumin. The supernatant solution was decanted and counted on a Packard gamma counter (model 3320, Packard Instrument Co., Inc., Downers Grove, Ill.) for $1 \mathrm{~min}$.

Enzyme treatment of fibrinogen. Each experiment was performed using human fibrinogen at a final concentration of $0.45 \mathrm{mg} / \mathrm{ml}$ in $0.1 \mathrm{M} \mathrm{NaCl}$ buffered with $0.05 \mathrm{M}$ Tris$\mathrm{HCl}$ at $\mathrm{pH} 7.4$. $900-\mu \mathrm{l}$ aliquots of fibrinogen at $0.5 \mathrm{mg} / \mathrm{ml}$ were incubated at $37^{\circ} \mathrm{C}$ with $100 \mu 1$ of enzyme for intervals ranging from 5 to $120 \mathrm{~min}$ and for $24 \mathrm{~h}$. Control samples of fibrinogen were incubated with buffer in place of enzyme at $37^{\circ} \mathrm{C}$ for $120 \mathrm{~min}$ and $24 \mathrm{~h}$. The reaction was stopped and the fibrinogen precipitated by the addition of $1 \mathrm{ml}$ of ethanol to each sample. The fibrinogen was deposited by centrifuging at $4,800 \mathrm{~g}$ at $4^{\circ} \mathrm{C}$ for $10 \mathrm{~min}$. The top $1 \mathrm{ml}$ of supernatant solution was transferred to a fresh tube and recentrifuged under the same conditions. Of this, the top $0.5 \mathrm{ml}$ was pipetted into a segment of dialysis tubing ( 1 inch inflated, Union Carbide Corp.) and dialyzed against $4.5 \mathrm{ml}$ of $0.1 \mathrm{M} \mathrm{NaCl}$ buffered with $0.05 \mathrm{M}$ Tris$\mathrm{HCl}$ at $\mathrm{pH} 8.6$ with $0.1 \%$ ovalbumin. Dialysis was carried out for $24 \mathrm{~h}$ at $10^{\circ} \mathrm{C}$ with constant mechanical rotation at 1 revolution per $6 \mathrm{~min}$ on a Bellco roller drum, (Bellco Glass, Inc., Vineland, New Jersey). The dialysates were stored at $-80^{\circ} \mathrm{C}$ and subsequently assayed for FPA using antiserum R33 (4) and for FPB using antiserum RB29 (Table II). For the experiments in which fibrinogen was incubated with plasmin, the dialysates were further treated with thrombin $1 \mathrm{U} / \mathrm{ml}$ for $2 \mathrm{~h}$ at $37^{\circ} \mathrm{C}$ before testing to be able to quantitate in molar terms the presence of fragments of the $\mathrm{A}(\alpha)$ and $\mathrm{B}(\beta)$ chains containing the $\mathrm{A}$ and $B$ peptides.

For each experiment, the values obtained for FPA and FPB in the dialysates were corrected by a factor obtained by similarly processing and dialyzing aliquots of radiolabeled peptide. $1 \mathrm{ml}$ each of radiolabeled FPA and FPB was precipitated with $50 \%$ ethanol, centrifuged, and dialyzed along with the samples, and the recovery of tracer in the dialysates was determined.

To determine the extent to which proteins of different sizes would pass through the dialysis membrane, the follow-

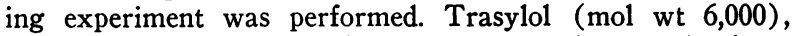
ribonuclease ( $\mathrm{mol}$ wt 13,700), chymotrypsinogen (mol wt

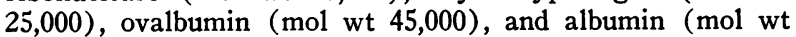
67,000 ) were each dialyzed for $24 \mathrm{~h}$ against $0.1 \mathrm{M} \mathrm{NaCl}$ buffered with $0.05 \mathrm{M}$ Tris- $\mathrm{HCl}$ at $\mathrm{pH} 7.4$, and the recovery of protein in the dialysate was determined spectrophotometrically. The recovery of Trasylol after $24 \mathrm{~h}$ of dialysis was $22 \%$, and was $1 \%$ or less for each of the other materials.

Calculation of enzyme and substrate concentrations. The enzymatic cleavage of fibrinogen was performed at a substrate concentration of $0.45 \mathrm{mg} / \mathrm{ml}\left(1.3 \times 10^{-6} \mathrm{M}\right)$. Thrombin was used at a concentration of $0.02 \mathrm{U} / \mathrm{ml}$, or $2.4 \times 10^{-10}$ 


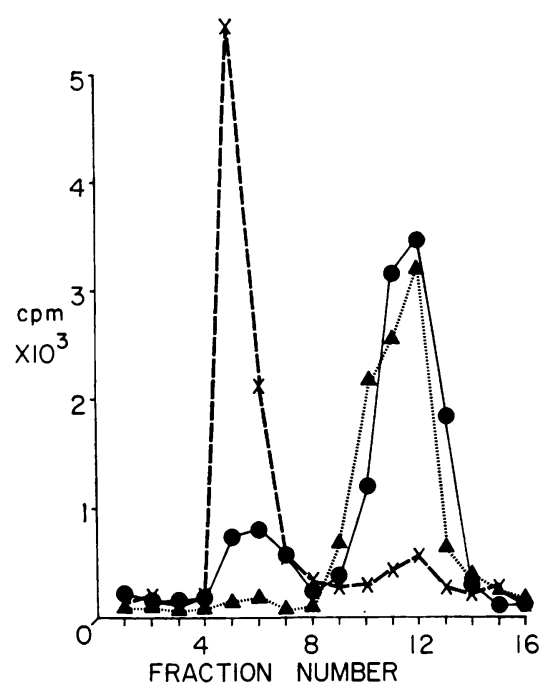

FIgURE 1 Gel filtration of labeled peptide. Radiolabeled desaminotyrosine-coupled FPB analogue was filtered through a $22 \times 0.8-\mathrm{cm}$ Sephadex G-100 column with $0.1 \mathrm{M}$ $\mathrm{NH}_{4} \mathrm{HCO}_{3}$ as eluant. The following mixtures were incubated at room temperature for $2 \mathrm{~h}$ before passage over the column. 1-ml fractions were collected. $50 \mu 1$ of labeled peptide ( $1 \mathrm{ng}$ ) and $400 \mu \mathrm{l}$ of $0.5 \mathrm{M}$ Tris buffer, $\mathrm{pH} 8.6$ (A). $50 \mu 1$ of labeled peptide, $350 \mu 1$ of Tris buffer and $50 \mu 1$ of $1 / 5$ antiserum RB22 $(\times)$. $50 \mu 1$ of labeled peptide, $100 \mu \mathrm{l}$ of synthetic FPB $(2 \mu \mathrm{g}), 325 \mu \mathrm{l}$ of buffer, and $50 \mu 1$ of $1 / 5$ antiserum RB22 (๑).

$\mathrm{M}$, assuming a sp act of $2,500 \mathrm{U} / \mathrm{mg}^{3}$ The plasmin concentration used was $0.01 \mathrm{mg} / \mathrm{ml}$. Assuming a mol wt of 75,000 (9), the concentration would be $1.25 \times 10^{-7} \mathrm{M}$. Since the sp act of the plasmin preparation was $10 \mathrm{U} / \mathrm{mg}$ and sp act of $25 \mathrm{U} / \mathrm{mg}$ have been described (10), it is possible that the molar plasmin concentration was less than calculated above. The trypsin concentration was $10^{-4} \mathrm{mg} / \mathrm{ml}$ which would be $4.2 \times 10^{-8} \mathrm{M}$ assuming a mol wt of 24,000 .

\section{RESULTS}

Antisera to human and bovine serum albumin and two antisera to fibrinogen bound insignificant amounts of radiolabeled peptide (Table $\mathrm{II}$ ). Preimmunization antisera from rabbits RB22, RB23, RB24, and RB29 bound insignificant amounts of radiolabeled peptide; however, after 3 mo of immunization with FPB-albumin conjugate, these antisera bound significant amounts of radiolabeled FPB (Table II). Antisera from rabbits RB22 and RB29 were the most active and were used in the subsequent experiments.

Binding of the radiolabeled peptide by antiserum and inhibition of binding by FPB was demonstrated by gel filtration experiments. As shown in Fig. 1, radiolabeled FPB eluted from the Sephadex G-100 column principally in tubes 11 and 12 . When the tracer was preincubated with antiserum RB22 before gel filtration,

\footnotetext{
'Aronson, D., Bureau of Biologics, Bethesda, Md.
}

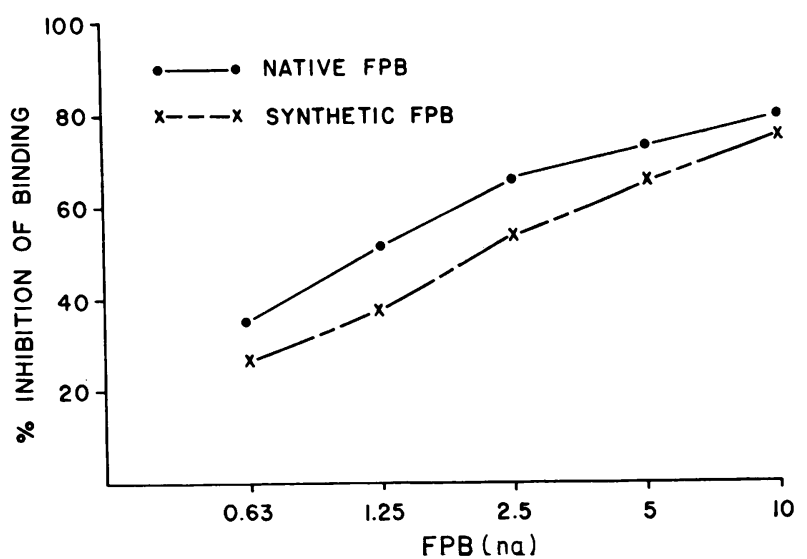

FIGURE 2 Standard curve showing inhibition of binding of radiolabeled desaminotyrosine-coupled FPB analogue by native FPB $(\bullet)$ and synthetic FPB $(X)$. Antiserum RB29 used in a $1 / 1,000$ dilution.

the radioactivity eluted principally in tube 5 . However, if the antiserum was incubated with excess native FPB in addition to the tracer, the tracer eluted from the column as if no antibodies were present.

When standard solutions of native and synthetic FPB were tested by radioimmunoassay, binding of the tracer to the antiserum was progressively inhibited by increasing quantities of FPB. $50 \%$ inhibition of binding was caused by $1.25 \mathrm{ng}$ of native or by $2.5 \mathrm{ng}$ of synthetic peptide (Fig. 2).

Antiserum from RB22 showed no reactivity with the various materials listed in Table III. Antisera from

TABLE III

Inhibition of Binding of Radiolabeled FPB to Antiserum RB22 by Various Materials

\begin{tabular}{lc}
\hline \multicolumn{1}{c}{ Substance } & $\begin{array}{c}\text { Quantity of } \\
\text { material causing } \\
50 \% \text { inhibition } \\
\text { of binding }\end{array}$ \\
FPB (native) & $\mu g$ \\
FPB (synthetic) & 0.0021 \\
FPB analogue (synthetic) & 0.0023 \\
FPA & 0.0029 \\
Cohn fraction II & $2^{*}$ \\
Cohn fraction III & $50^{*}$ \\
Cohn fraction IV & $10^{*}$ \\
Cohn fraction V & $50^{*}$ \\
Lysozyme & $100^{*}$ \\
Bovine serum albumin & $100^{*}$ \\
Human serum albumin & $200^{*}$ \\
Insulin & $200^{*}$ \\
Bradykinin & $1^{*}$
\end{tabular}

* No inhibition of binding at these concentrations. 

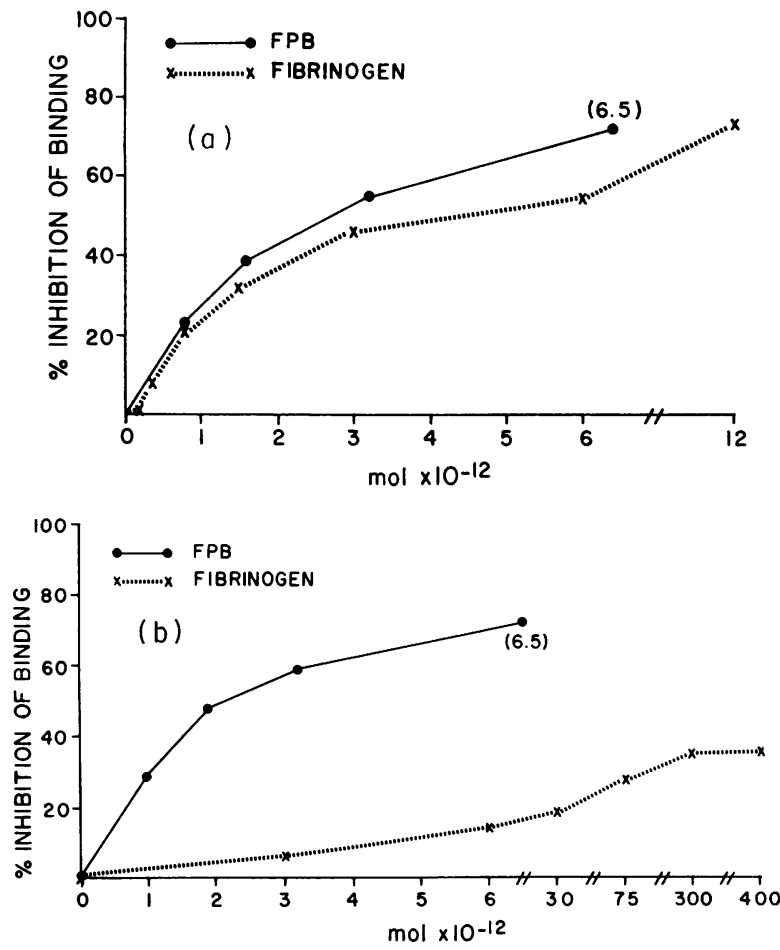

FJGURE 3 (a) Inhibition of binding of ${ }^{125}$ I-labeled desaminotyrosine-coupled FPB analogue by native FPB and by fibrinogen (dialyzed Kabi fibrinogen was used in this experiment) using antiserum RB29 (1/1,500 final concentration). (b) As for (a) except that RB22 antiserum was used.

RB22 and RB29 both cross-reacted with fibrinogen, but their patterns of reactivity were different. In the case of antiserum RB29, fibrinogen was only slightly less reactive than FPB in inhibiting binding of the tracer (Fig. 3a). In the case of antiserum RB22, fibrinogen was significantly less reactive than FPB in

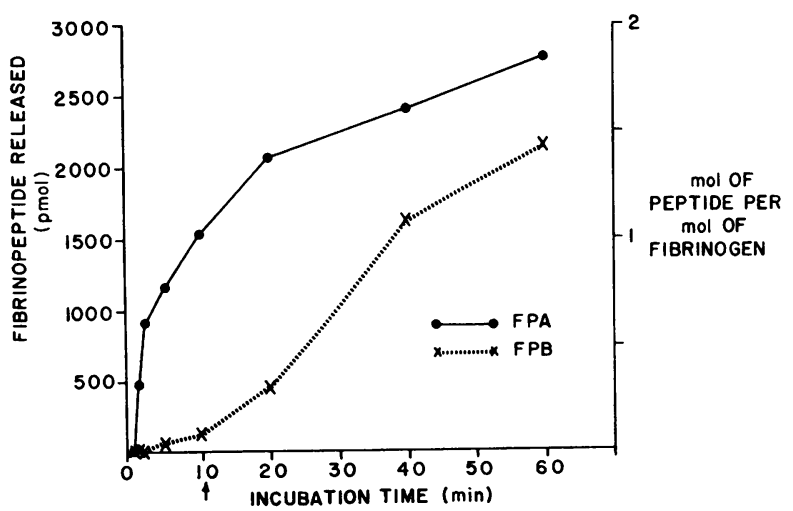

FIgURE 4 Cleavage of FPA and FPB from fibrinogen by thrombin. The fibrinogen concentration was $0.45 \mathrm{mg} / \mathrm{ml}$, the thrombin concentration $0.02 \mathrm{U} / \mathrm{ml}$, the $\mathrm{pH} 7.4$, ionic strength $0.15 \mathrm{M}$ and the incubation temperature $37^{\circ} \mathrm{C}$. The appearance of visible clotting is marked by the arrow $(\uparrow)$.

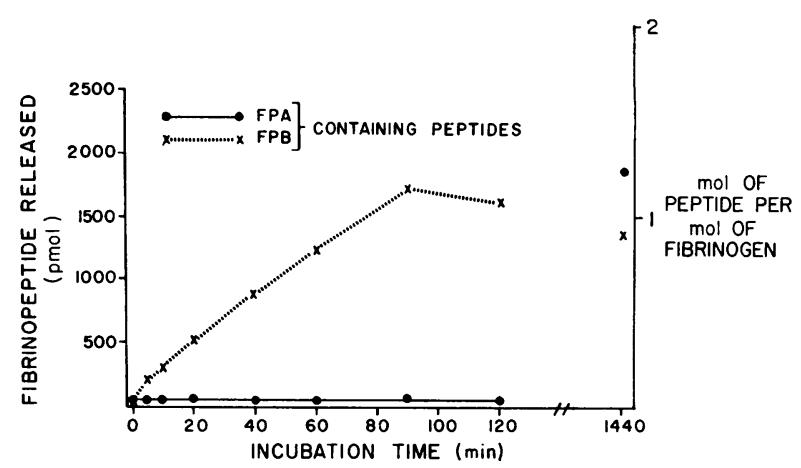

FIgURe 5 Cleavage of FPA and FPB containing peptides from fibrinogen by plasmin. The fibrinogen concentration was $0.45 \mathrm{mg} / \mathrm{ml}$, the plasmin concentration $0.1 \mathrm{U} / \mathrm{ml}(0.01$ $\mathrm{mg} / \mathrm{ml}$ ), the $\mathrm{pH} 7.4$, ionic strength $0.15 \mathrm{M}$, and the temperature $37^{\circ} \mathrm{C}$.

inhibiting binding of the tracer, so that up to $400 \mathrm{pmol}$ of fibrinogen inhibited binding by only $38 \%$ (Fig. $3 b$ ).

Application of the FPB assay and the previously developed FPA assay to the study of the kinetics of enzymatic cleavage of the two peptides from fibrinogen confirmed that different enzymes had distinctive cleavage patterns. Incubation of fibrinogen with thrombin resulted in an initial rapid release of FPA, with a slower release of FPB (Fig. 4). The rate of release of FPB appeared to increase after cleavage of $1 \mathrm{~mol}$ FPA per mol of fibrinogen. At $60 \mathrm{~min} 1.8 \mathrm{~mol} \mathrm{FPA}$ and $1.4 \mathrm{~mol}$ FPB had been recovered per mol of fibrinogen. Incubation of fibrinogen with plasmin resulted in cleavage of a segment or segments of the amino terminal end of the $B(\beta)$ chain which included the $B$ peptide. There was no detectable release of FPAcontaining material for the first $2 \mathrm{~h}$ of incubation (Fig. 5 ). After $24 \mathrm{~h}$ of incubation considerable amounts of FPA-containing segments had been released equivalent to the total amount of FPB-containing material. Incubation of fibrinogen with trypsin resulted in a rapid cleavage of the amino terminal ends of both the $\mathrm{A}(\alpha)$ and $B(\beta)$ chains. The $B$ peptide or a segment containing it appeared somewhat faster than the A (Fig. 6). There appeared to be an increase in the cleavage rate for both peptides after $15 \mathrm{~min}$ incubation. After $24 \mathrm{~h}, 2.2 \mathrm{~mol}$ of FPB immunoreactivity and $1.6 \mathrm{~mol}$ of FPA immunoreactivity were recovered per $\mathrm{mol}$ of fibrinogen.

The effects of the two snake venoms tested on fibrinogen were also distinctive. Reptilase cleaved the A peptide from fibrinogen completely in $2 \mathrm{~h}$, with no detectable release of the $\mathrm{B}$ peptide even after $24 \mathrm{~h}$ of incubation (Fig. 7). On the other hand, ACC cleaved the $B$ peptide from fibrinogen at a rapid initial rate, with a slower release of the A peptide (Fig. 8). After $24 \mathrm{~h}$ approximately $1.6 \mathrm{~mol}$ of each peptide had been recovered per mol of fibrinogen. 


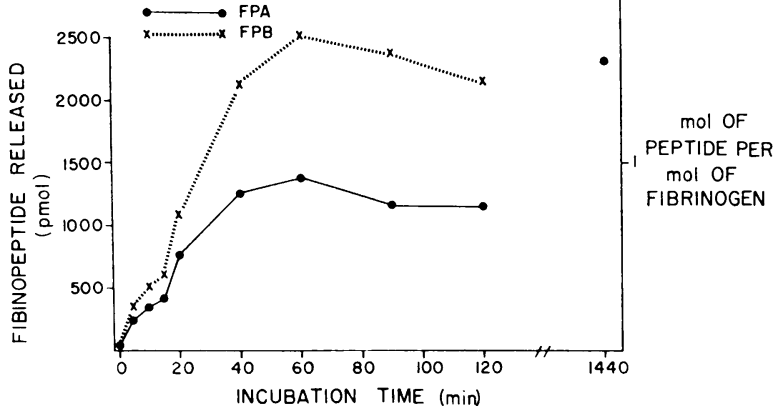

FIGURE 6 Cleavage of FPA and FPB from fibrinogen by trypsin. The fibrinogen concentration was $0.45 \mathrm{mg} / \mathrm{ml}$, the trypsin concentration was $10^{-4} \mathrm{mg} / \mathrm{ml}$, the $\mathrm{pH} 7.4$, ionic strength $0.15 \mathrm{M}$, and temperature $37^{\circ} \mathrm{C}$.

\section{DISCUSSION}

The data indicate that a specific and sensitive radioimmunoassay for human FPB can be performed with the use of radiolabeled $N$-desaminotyrosyl FPB and antisera from rabbits immunized with FPB analoguealbumin conjugates. The assay is sensitive enough to measure accurately $1.25 \mathrm{ng}$ of native FPB (50\% inhibition of binding) (Fig. 2). A fourfold increase in sensitivity can be obtained by using a preincubation technique. The specificity of the assay for FPB is high in comparison with other proteins (Table III). Crossreactivity with fibrinogen differed significantly with the two antisera tested. With antiserum RB29 crossreactivity was nearly complete, whereas much more limited cross-reactivity occurred with antiserum RB22. This result implies that the antigenic determinant on the peptide which reacts with antiserum RB22 is partly occluded in the intact fibrinogen molecule. When dialysates of streptokinase-treated plasma were tested with RB22 antiserum, a five-fold increase in immunoreactivity occurred after treatment of the dialysate with thrombin (data not shown). Since the dialysis membrane is relatively impermeable to large molecules, it is likely that the dialysate of streptokinase-treated plasma contains small molecular weight peptides (possibly $\mathrm{B}(\beta)$ 1-42) produced by plasmin cleavage from the $\mathrm{NH}_{2}$-terminal end of the $\mathrm{B}(\beta)$ chain of fibrinogen, and that the antigenic determinant which reacts with RB22 is also partly hidden in these small peptides. If these speculations are correct, the results are analogous to the finding that in the FPA assay the R2 antigenic determinant is unavailable in the $\mathrm{A}(\alpha)$ 1-23 segment (4). The practical consequence of such results would be that it would be possible to identify the presence or absence of the $B(\beta) 1-42$ peptide in clinical blood samples by immunochemical means as was done for the FPA assay (4).

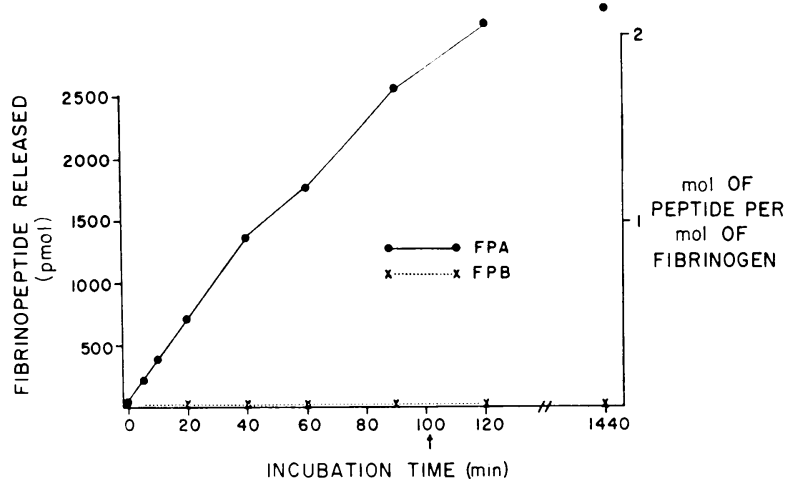

Figure 7 Cleavage of FPA and FPB from fibrinogen by Reptilase. The fibrinogen concentration was $0.45 \mathrm{mg} / \mathrm{ml}$, the Reptilase concentration was $5 \times 10^{-6} \mathrm{mg} / \mathrm{ml}$, the $\mathrm{pH}$ 7.4 , the ionic strength $0.15 \mathrm{M}$, and the temperature $37^{\circ} \mathrm{C}$.

In considering the kinetics of peptide cleavage by enzymes, the finding that thrombin cleaves FPA faster than FPB confirms the observations of Blombäck and Vestermark (2), of Bettelheim (11), of Shainoff and Page (12), and of Abildgaard (13). The rate of FPA cleavage in the present study is similar to that noted by Abildgaard (13) and by Blombäck and Vestermark (2). The signal for the release of FPB by thrombin is not known but it appears from the data in Fig. 4 that the rate of FPB cleavage increases markedly after approximately $1 \mathrm{~mol}$ of FPA has been cleaved per mol of fibrinogen, and also after visible clotting has occurred. A possible explanation for the increased rate of FPB cleavage is that conformational changes in the fibrinogen molecule which accompany cleavage of FPA render the FPB cleavage site more accessible to thrombin. An alternative explanation is that the FPA cleavage site acts as a competitive inhibitor for the FPB cleavage site and

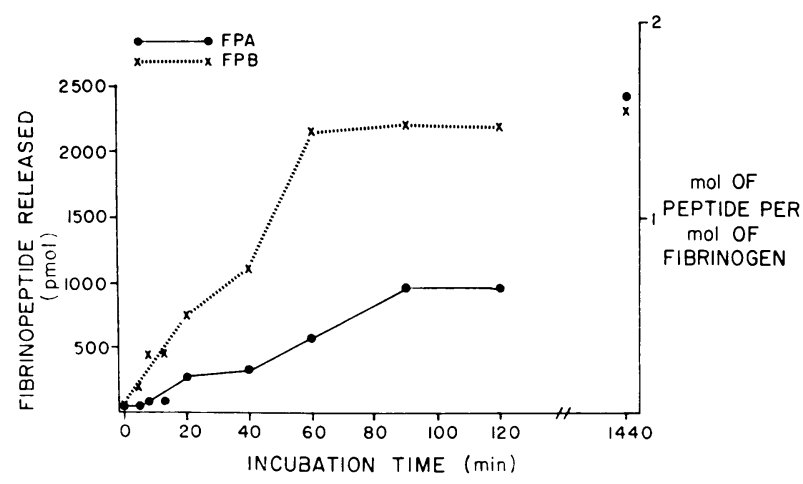

Figure 8 Cleavage of FPA and FPB from fibrinogen by an extract of the procoagulant fraction of the venom of ACC. The fibrinogen concentration was $0.45 \mathrm{mg} / \mathrm{ml}$, the ACC concentration was $2 \mu 1 / \mathrm{ml}(50 \mu \mathrm{l}$ ACC clots $1 \%$

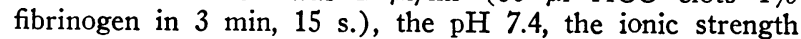
$0.15 \mathrm{M}$, and the temperature $37^{\circ} \mathrm{C}$. 
the inhibition is reduced as the concentration of available FPA cleavage sites falls.

The finding that plasmin cleaves FPB containing peptide but initially releases no detectable FPA containing peptide is consistent with the observations of others. Shainoff, Lahiri and Bumpus $(14,15)$, Budzynski, Marder, and Shainoff (16), Kierulf (17), and Kowalska-Loth, Gardlund, Egberg, and Blombäck (18) all noted the absence of FPB in fibrinogen derivatives resulting from limited plasmin proteolysis. The size and composition of FPB containing peptides cleaved by plasmin is not known. In this study, the peptides released from enzyme-treated fibrinogen were extracted by ethanol precipitation, centrifugation, and dialysis. The results of the experiments in which proteins of different sizes were dialyzed indicate that the passage of molecules of $13,700 \mathrm{~mol} \mathrm{wt}$ or greater is very slow. Hence the extracts almost certainly do not contain fragment $\mathrm{E}$ which is approximately $60,000 \mathrm{~mol} \mathrm{wt} \mathrm{(18).}$ Although the Arg (14)-Gly (15) bond in sulfitolyzed $\mathrm{B}(\boldsymbol{\beta})$ chains of fibrinogen is not cleaved by plasmin, about nine peptide bonds between Gly (15) and Ala (59) on the $B(\beta)$ chain are susceptible to plasmin cleavage (19), and the FPB containing segments monitored in the present study could reflect cleavage at one or more of these sites. In the present study the extracts of plasmin-treated fibrinogen were treated with thrombin before assay. In this way the number of moles of FPB containing peptide in the dialysate could be quantitated. The finding that substantial quantities of FPA containing peptide were released after $24 \mathrm{~h}$ may be compared with the findings of other workers on the fibrinopeptide content of plasmin degraded fibrinogen. Kowalska-Loth and colleagues (18) found that preparations of fragment $E$ derived from plasmindegraded fibrinogen still released FPA on treatment with thrombin. Budzynski and colleagues (16) and Mosesson, Finlayson, and Galanakis (20) have observed that early $\mathrm{E}$ contains FPA, while late $\mathrm{E}$ lacks FPA. It is difficult to exclude the presence of minute amounts of thrombin in the incubation mixture. Thrombin at $2 \times 10^{-6} \mathrm{U} / \mathrm{ml}$ could produce the amount of FPA released in $24 \mathrm{~h}$ in Fig. 5. In experiments in which hirudin was in the incubation mixture, significantly smaller amounts of FPA immunoreactivity were released. It is possible that small amounts of thrombin were generated over $24 \mathrm{~h}$ of incubation, which in the absence of hirudin acted to cleave the FPA. The fact that no detectable immunoreactivity was released in the first $120 \mathrm{~min}$ implies that a change in the reactants was required for FPA immunoreactivity release. Possible changes include thrombin generation, a specific molecular change in the fibrinogen molecule, or reduction in the competitive inhibitory effect of alternative cleavage sites as the concentration of these drops during continuing proteolysis.

The cleavage of both peptides from fibrinogen by trypsin (Fig. 6) is consistent with the findings of previous investigators. Pechet and Alexander (21) and Mihalyi and Godfrey (22) found that early in the course of trypsin action, fibrinogen showed no further reactivity to thrombin, suggesting that the bonds susceptible to thrombin had been cleaved. Wallén found that trypsin cleaves the bonds susceptible to thrombin as well as other sites in the $A(\alpha)$ and $B(\beta)$ chains (19). The fact that FPB cleavage is more rapid than FPA cleavage has not been described previously. The finding that Reptilase cleaves the A peptide but not the B (Fig. 7) confirms the observations of Blombäck and Yamashina (1). The finding that ACC cleaves the B peptide at a faster initial rate than the A (Fig. 8) is consistent with the report of Herzig, Ratnoff, and Shainoff, who studied the effects of the whole venom on fibrinogen (23).

The results of the enzyme studies show that the serine proteases thrombin, plasmin, and trypsin do have distinctive in vitro patterns of cleavage of the $\mathrm{NH}_{2}-$ terminal ends of the $A(\alpha)$ and $B(\beta)$ chains of fibrinogen. In addition, it is clear that there are marked differences in the quantitative effectiveness with which they cleave this end of the molecule. Thrombin is the most effective, trypsin next and plasmin is the least effective. The distinctive patterns of cleavage of the $\mathrm{NH}_{2}$-terminal ends of the $\mathrm{A}(\boldsymbol{\alpha})$ and $\mathrm{B}(\boldsymbol{\beta})$ chains of fibrinogen by different enzymes may provide a method for specifically indentifying the action of the enzymes in clinical blood samples. Generation rates of the two fibrinopeptides may be studied in clinical blood samples as well as the relative levels of the peptides in the blood. The data from the present studies indicate that FPA immunoreactivity is more likely to reflect thrombin action and FPB immunoreactivity plasmin action in vivo.

\section{ACKNOWLEDGMENTS}

We would like to acknowledge the excellent technical assistance of Rita Chatpar, Kalliope Spanondis, and Michael Drillings.

This work was supported by research grants from the National Institutes of Health (Program Project grants HL-15486 and HL-15596 and SCOR grant HL-14236).

\section{REFERENCES}

1. Blombäck, B., and I. Yamashina. 1958. On the Nterminal amino acids in fibrinogen and fibrin. Ark. Kemi. 12 : 299-319.

2. Blombäck, B., and A. Vestermark. 1958. Isolation of fibrinopeptides by chromatography. Ark. Kemi. 12: 173182.

3. Nossel, H. L., L. R. Younger, G. D. Wilner, T. Procupez, R. E. Canfield, and V. P. Butler, Jr. 1971 
Radioimmunoassay of human fibrinopeptide A. Proc. Natl. Acad. Sci. U. S. A. 68:2350-2353.

4. Nossel, H. L., I. Yudelman, R. E. Canfield, V. P. Butler, Jr., K. Spanondis, G. D. Wilner, and G. D. Qureshi. 1974. Measurement of fibrinopeptide A in human blood. J. Clin. Invest. 54: 43-53.

5. Blombäck, B., M. Blombäck, P. Edman, and B. Hessel. 1966. Human fibrinopeptides. Isolation, characterization and structure. Biochim. Biophys. Acta. 115: 371-396.

6. Miller, K. D., and W. H. Copeland. 1965. Human thrombin: isolation and stability. Exp. Mol. Pathol. 4: 431-437.

7. Goodfriend, T. L., and D. L. Ball. 1969. Radioimmunoassay of bradykinin: chemical modification to enable use of radioactive iodine. J. Lab. Clin. Med. 73: 501-511.

8. Hunter, W. M., and F. C. Greenwood. 1962. Preparation of iodine-131 labelled human growth hormone of high specific activity. Nature (Lond.). 194: 495-496.

9. Barlow, G. H., L. Summaria, and K. C. Robbins. 1969. Molecular weight studies on human plasminogen and plasmin at the microgram level. J. Biol. Chem. 244: 1138-1141.

10. Robbins, K. C., and L. Summaria. 1970. Human plasminogen and plasmin. Methods Enzymol. 19: 184-199.

11. Bettelheim, F. R. 1956. The clotting of fibrinogen. II. Fractionation of peptide material liberated. Biochim. Biophys. Acta. 19 : 121-130.

12. Shainoff, J. R., and I. H. Page. 1960. Cofibrins and fibrin-intermediates as indicators of thrombin activity in vivo. Circ. Res. 8: 1013-1022.

13. Abildgaard, U. 1965. N-terminal analysis during coagulation of purified human fibrinogen, fraction I, and plasma. Scand. J. Clin. Lab. Invest. 17: 529-536.

14. Shainoff, J. R., B. Lahiri, and F. M. Bumpus. 1970.
Ultracentrifuge studies on the reaction between thrombin and plasminized fibrinogen. Thromb. Diath. Haemorrh. 39(Suppl.) : 203-217.

15. Lahiri, B., and J. R. Shainoff. 1973. Fate of fibrinopeptides in the reaction between human plasmin and fibrinogen. Biochim. Biophys. Acta. 303: 161-170.

16. Budzynski, A. Z., V. J. Marder, and J. R. Shainoff. 1974. Structure of plasmic degradation products of human fibrinogen. Fibrinopeptide and polypeptide chain analysis. J. Biol. Chem. 249: 2294-2302.

17. Kierulf, P. 1972. N-terminal analysis of 'fibrins' from plasmin hydrolysed fibrinogen - evidence for lack of fibrinopeptide B. Thromb. Res. 1: 527-532.

18. Kowalska-Loth, B., B. Gårdlund, N. Egberg, and B. Blombäck. 1973. Plasmic degradation products of human fibrinogen. II. Chemical and immunological relation between fragment E and N-DSK. Thromb. Res. 2: 423450.

19. Wallén, P. 1971. Plasmic degradation of fibrinogen Scand. J. Haematol. Suppl. 13: 3-14.

20. Mosesson, M. W., J. S. Finlayson, and D. K. Galanakis. 1973. The essential covalent structure of human fibrinogen evinced by analysis of derivatives formed during plasmic hydrolysis. J. Biol. Chem. 248: 7913-7929.

21. Pechet, L., and B. Alexander. 1962. The effect of certain proteolytic enzymes on the thrombin-fibrinogen interaction. Biochemistry. 1: 875-883.

22. Mihalyi, E., and J. E. Godfrey. 1963. Digestion of fibrinogen by trypsin. I. Kinetic studies of the reaction. Biochim. Biophys. Acta. 67: 73-89.

23. Herzig, R. H., O. D. Ratnoff, and J. R. Shainoff. 1970. Studies on a procoagulant fraction of southern copperhead venom: the preferential release of fibrinopeptide B. J. Lab. Clin. Med. 76: 451-465. 